\title{
The highway and the American city
}

\author{
T. Shelton \\ University of Tennessee, USA
}

\begin{abstract}
This paper traces the history of the difficult relationship between the highway and the American city. The highway/urban interface is seen as the site of a struggle for primacy between the infrastructure of the highway, which prioritizes speed and individual experience, and types of 'gentle infrastructures' that support the intricate interactions of groups of people in complex urban environments. Particular attention is given to the inequities that arise as a result of the conflict between these two types of infrastructure - inequities that have both social and environmental dimensions and that eventually sparked numerous revolts against urban highways.

This conflict is set against the backdrop of the early development of the highway in America as a predominantly rural phenomenon. The highway is seen both as playing an important role in the economic development of the American countryside and as serving as a means through which ideas about national identity were projected onto the continental landscape. In the countryside at large scales and high speeds, and nearly without conflicting 'gentle infrastructure', the social reading of the highway is a predominately positive one, although its environmental impact remains somewhat troubling. It is suggested then that failure to understand how social interpretation of the highway must change with its context led to its misapplication in the American city.

Finally, the paper examines the recent trend of eliminating urban segments of the highway system. It is suggested that this movement presents the possibility of introducing numerous environmentally progressive infrastructures into the fabric of the city, which might otherwise be too crowded to receive them.
\end{abstract}

Keywords: urban, infrastructure, highway, cities. 


\section{The car comes to the city}

Almost since its invention, the automobile has had an uneasy relationship with the American city. On September 13, 1899 Henry Bliss was struck by a cab at the intersection of Central Park West and Seventy-Fourth Street in New York City. He died from his injuries the next morning earning the unwanted distinction of being the first automobile fatality in North America [1]. The details of the event are so unusual as to seem constructed for some allegorical purpose. At the time of the accident, the victim was disembarking from what might be seen as a more benign and egalitarian form of urban transit - a streetcar. The passenger in the cab was both a physician returning from a house call and the son of a former New York City mayor. He cared for Bliss in the street to no avail. Can we understand him as a symbol of a bygone era of American urban leaders who, despite their skills, were unprepared to lead cities into the age of the automobile? The deadly vehicle on that day was not the clattering rig that one envisions when thinking of a $19^{\text {th }}$ century automobile. It represented the very technology that many today, 110 years after that fateful accident, see as holding the promise of finally reconciling the troubled relationship between the automobile and the city. It was an electric car [2].

It is not surprising for this first accident to have occurred in a city rather than in the countryside. In cities cars and pedestrians are in close proximity traveling on systems of intersecting paths amid countless distractions. As cars infiltrated the American city they co-opted infrastructure, the city streets, that had originally been designed for other types of users - wagons, trolleys, horses, and even bicycles and pedestrians. Despite the accident that claimed Bliss' life, early on this arrangement must have been largely a satisfactory one. After all, how different is an automobile (a "horseless carriage) from a horse-drawn wagon? Yet, soon the automobile's growing popularity and increasing speed began to exacerbate the early tensions between the car and the city. In 1901 Connecticut became the first state to place legal limits on automobile speeds $-12 \mathrm{mph}$ in the city, $15 \mathrm{mph}$ in the countryside [3].

\section{The car in the American countryside}

This differentiation by the Connecticut legislature of urban and rural speed limits is insightful. It suggested a difference in the ease with which the automobile might be absorbed into these two very different landscapes - a difference predominantly related to one variable - speed. Like a train, a car in motion does not "want" to stop. It is most efficient, safe, and pleasurable in the static state of a constant speed. Conversely, when perturbed into a dynamic mode of acceleration or (more likely) deceleration by an intersection, obstacle, or curve efficiency drops, bodies begin to slide around the passenger compartment, or the now unstable car leaves the road altogether. Unlike a train however, the automobile is under the control of an individual and is not bound by a system of tracks. Conceptually, a car might be operated by anyone to travel anywhere. 
Therefore, as cars became faster and more commonplace the allure of the American road grew accordingly. It was first in the American countryside that the desires of automobile drivers began to spark the creation of a new type of infrastructure - the highway [4]. While the city inherently presented numerous obstacles and intersections that made high speed car travel impractical, the nation's vast undeveloped areas offered the ideal automobile environment.

Work on the nation's first transcontinental highway, the Lincoln Highway, began in 1913. While this coast-to-coast spine certainly had implications for commerce and industry, its poetic implications on the American imagination should not be underestimated. Indeed, the association that pushed for the Lincoln Highway's construction did so with the slogan, "Let's build it before we are too old to enjoy it", suggesting a measure of personal indulgence attached to the road [5]. Yet, as egalitarian as transcontinental mobility might seem, it could undoubtedly only be enjoyed by a small portion of the American population of the time - those with the resources to own and maintain a car in frequent need of mechanical attention and the flexibility to entertain the possibility of being on the road for days or even weeks at a time. Indeed, during his time as the president of Princeton University (1902-1910), Woodrow Wilson proposed that the automobile be outlawed so as to not widen the disparities between the rich and the poor [5]. Yet, while the potential ridership of the idealized car moving across the American landscape was small, it coincided neatly with the power elite of the day - political, business, and industry leaders. So, the construction of the Lincoln Highway, and eventually many others, proceeded.

It is interesting to note that, while only relatively few Americans of the day could even dream of hitting the open road, even for these such ideas remained, for many years, just that - a dream. It wasn't until 1919, for example, that the United States Army attempted its first transcontinental motorcade. The trip from Washington DC to San Francisco required sixty-two days and an incredible amount of resources. So compelling was the undertaking that 3.5 million people turned out to line the route. The trek is most widely remembered today for, "the lasting effect it had on just one of its participants - a young Army lieutenant", Dwight D. Eisenhower, who later as President would be instrumental in the establishment of the interstate highway system that now bears his name [6].

While consolidation of the of the Lincoln Highway may have been motivated largely by selfish desires, before long there were those who were envisioning the highway as an agent for positive social change. Spurred by ideas first presented by the forester and planner Benton MacKaye, planners at the Tennessee Valley Authority (TVA) in the mid 1930's sought to fully integrate highway construction into their work, which endeavored to provide social benefit through flood mitigation, economic development, and rural electrification. TVA planners "saw the freeway as a means of accelerating the economic development of the region. It would allow truck traffic to flow more easily; linking dispersed production to dispersed markets. It would bring tourists into the region, enabling them to consume the scenery and purchase the craft commodities. Contained within arteries, traffic would circulate through the 'organic machine' and feed its 
systems of exchanges...In this way, the once isolated, underdeveloped region would be knit into a national economy on its way to recovery" [7, pp. 198-199].

To a great extent, this is exactly what rural highways in America did and continue to do. In allowing small towns to be part of a larger, interconnected, transportation system, the highway in the American countryside has been a success. Out in the vast continent not only was the highway able to let the automobile have its head, moving at ever greater speeds unperturbed by the hazards of the city but it was able, at its best, to do so in a lyrical, cinematic way that was not lost on the planners at the TVA [7, pp. 199-200] (Figure 1).

Yet, this was not to be a formula that held true in American cities. MacKaye's essay on the social and poetic possibilities used by the TVA to great effect was entitled "The Townless Highway". In it he, "did not suggest continuous development along this vehicular spine, on the contrary...[h]e wanted 'highwayless towns' to be set slightly apart from the freeway, so that they would

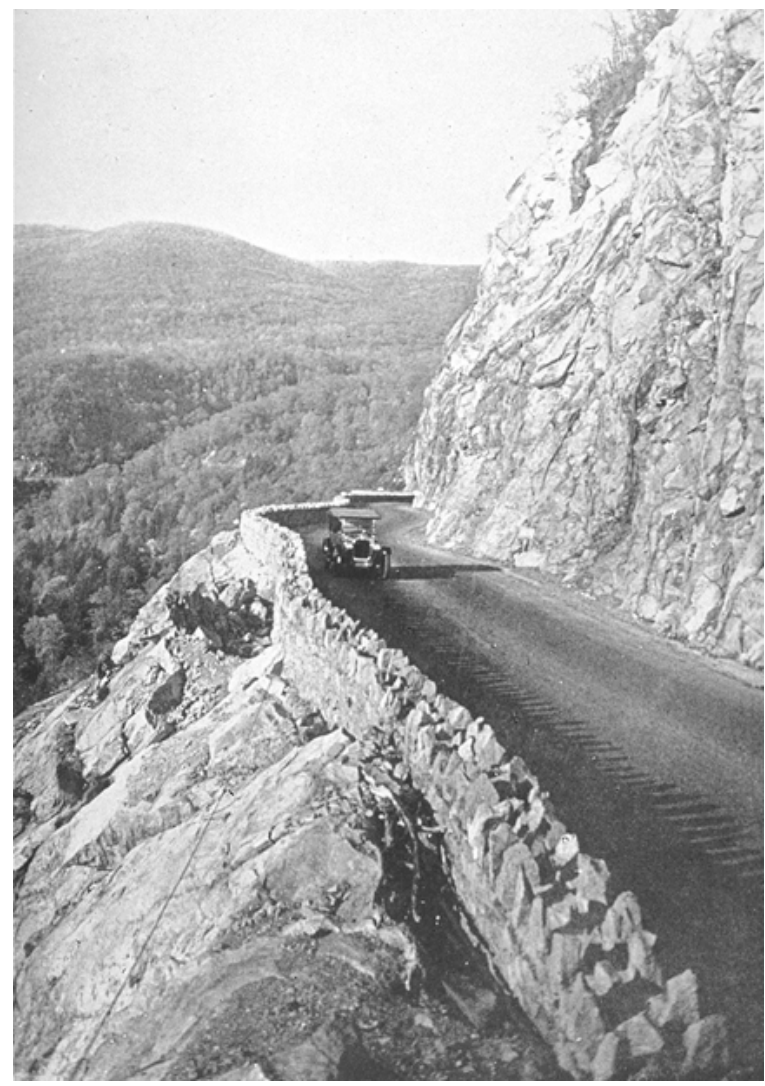

Figure 1: The car in the American countryside. Palisades interstate park, NJ. Courtesy of the Frances Loeb library, graduate school of design, Harvard University. 


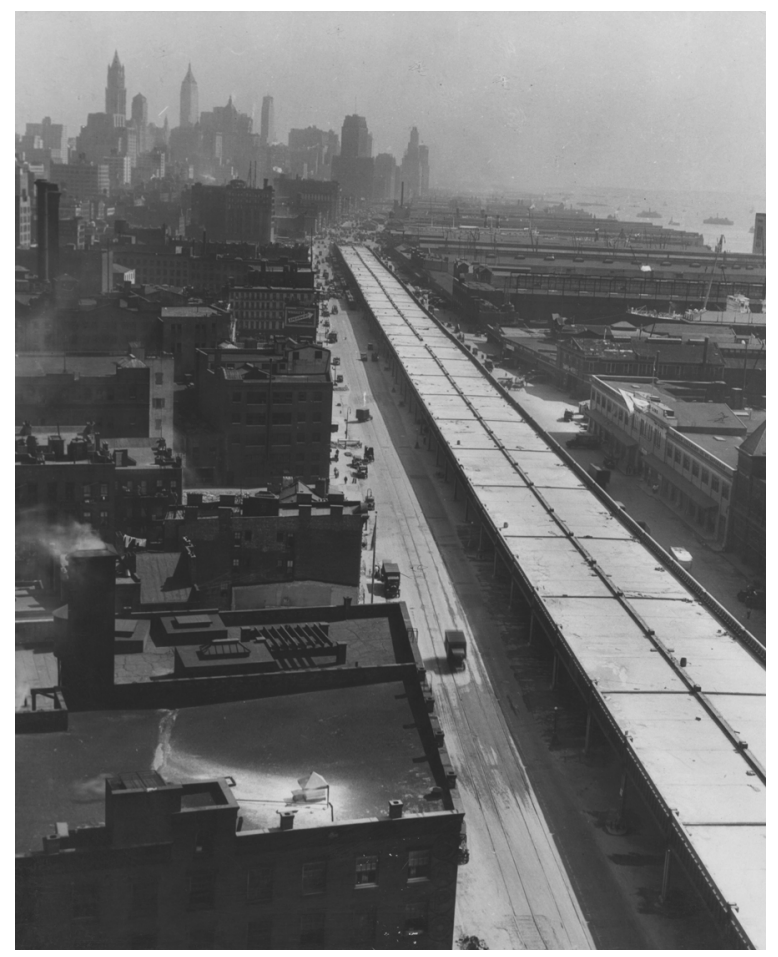

Figure 2: The highway and the city. West side highway 1930, courtesy of the New York public library.

be free from the dangerous through traffic and unsightly billboards and strips." Yet, in 1930, the very year that MacKaye published his essay; the West Side Highway was pushing into New York City [7, p. 198] (Figure 2).

\section{The highway comes to the city}

"Highways with their high-speed geometrics, in fact, should never have entered towns... Why? Because a highway is a rural typology...so you don't bring it into the city because it's destructive, and you don't let the city grow out along it...we destroyed our cities and consumed our countryside...because we misunderstood the definition of highway." [8]

\section{- Andres Duany}

Michael Pollan suggests that all design can be understood as a negotiation between "there" and "here"; that is, between abstract cultural notions of the wider world and the concrete reality of a place [9]. In these terms, the "there" of the romantic allure of the car in the American rural landscape seems to have been 
too powerful to shake even when faced with the difficult "here" of the American city. No longer was the automobile content to simply occupy city streets with their obstacles and distractions. Now the car was pushing into the city and bringing its own infrastructure - the highway - along with it (Figure 3).

This intrusion of automobile-centric infrastructure, which was benign or even picturesque in the rural landscape, into the urban fabric where it conflicted with the densely layered infrastructures and patterns of the city, unavoidably raises basic questions of social equity. The freedom and convenience afforded the driver must be weighed against the safety of the pedestrian and the quality of the urban environment. With car ownership acting as an economic threshold, the two sides of this conflict - the highway user and the city inhabitant - came to be organized in terms of economic status and, as a result, oftentimes by race.

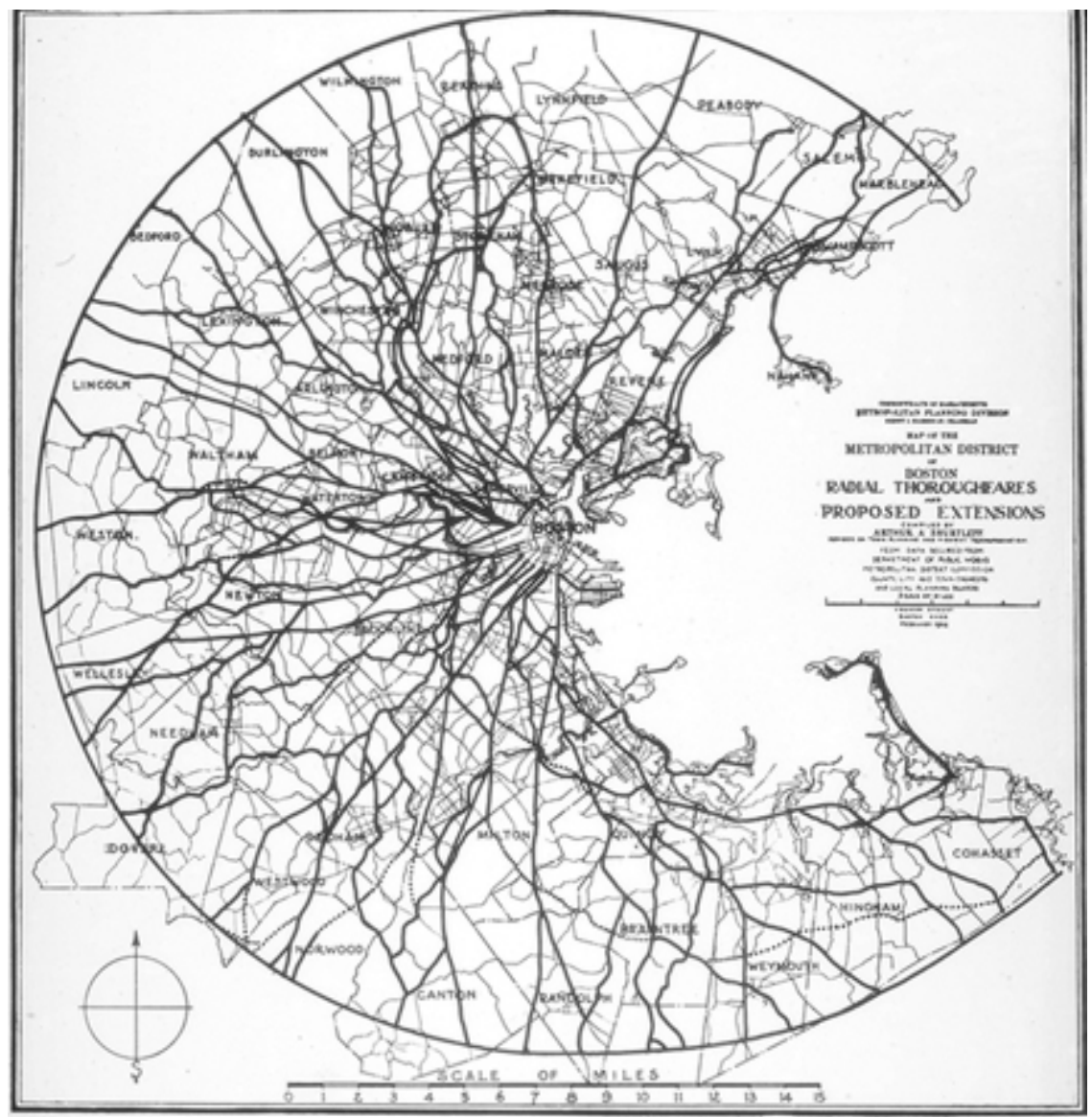

Figure 3: The highway pushes in toward the city core. Boston, MA, radial thoroughfares and proposed extensions. Courtesy of the Frances Loeb library, graduate school of design, Harvard University. 
However, the planners and urban leaders of the day could be partially excused if they believed (as apparently most sincerely did) that a state of détente might be forged between the competing forces of the highway and the city if not, in fact, a mutually beneficial symbiotic relationship. Beginning with Tony Garnier's Une Cité Industrielle in 1918, utopian urban plans of the early $20^{\text {th }}$ century are rife with visions of highways effectively and seamlessly connecting the city to the surrounding landscape. No influential utopian ideal of the era is without this recurring trope. Le Corbusier's Plan Voisin of 1925 and La Ville Radieuse of 1935 contain this idea. It is practically the central theme of the highly influential Futurama exhibit, the centerpiece of the 1939 World's Exposition, which "presented a utopia forged by urban planning. Sophisticated highways ran through rural farmland and eventually moved into carefully ordered futuristic cities" [10]. It even makes an appearance in Frank Lloyd Wright's Arcadian Broadacre City. It is perhaps unsurprising that three of these projects; Plan Voisin, La Ville Radieuse, and Futurama; were underwritten by car companies.

This hope of uniting the American city with the countryside, and its role in the American psyche, was not new. Indeed, many of the hopes being placed in the automobile in the early $20^{\text {th }}$ century had first been attached to the railroad by writers in the early $19^{\text {th }}$ century. In The Machine in the Garden, Leo Marx recounts a bit of rhetoric from the 1830's in which the railroad is seen as helping to usher in an American future containing, "a large share of the knowledge, refinement, and polish of a city, united to the virtue and purity of the country" [11]. However, railroads with their limited number of tracks and corporate rather than individual control, while disruptive in the city, never posed the difficulties that highways would present. As one reporter for the Baltimore Sun would later put it, "'blending' a six or eight-lane highway into the fabric of [the city] is about as promising an assignment as 'blending' a buzz saw into a Persian rug” [12].

Following the West Side Highway, by the 1950's many American cities had constructed elevated urban highways. These projects, such as Boston's Central Artery, the Embarcadero Freeway in San Francisco, and the Alaskan Way Viaduct in Seattle, seem to speak of the difficulty of 'blending' the city and the highway by virtue of their very form. The elevated roadways seem reluctant to set down among the obstacles of the urban environment. As Keller Easterling has put it, "The highway was legislated as an intercity network, yet it was not specialized to interface with the complexities of the city" [13]. Of course, even this effort at separating the high speed world of the highway and the everyday world of the city introduced a literal underside that was dark, unpleasantly reverberant, and foreboding as well as creating thick walls in the city effectively separating one district from another [14] (Figure 4). In addition to these obvious concerns though, with this spate of elevated urban highway construction, there was another conflict brewing that was less obvious, at least to those not directly affected. For ease of construction many of these early elevated highways aligned with wide existing boulevards. However, at some point or another, they eventually had to diverge from this relatively generous right of way and when they did buildings and city streets were necessarily displaced. It was this act, not only of creating an aesthetic affront (and a considerable one) to life of the city 


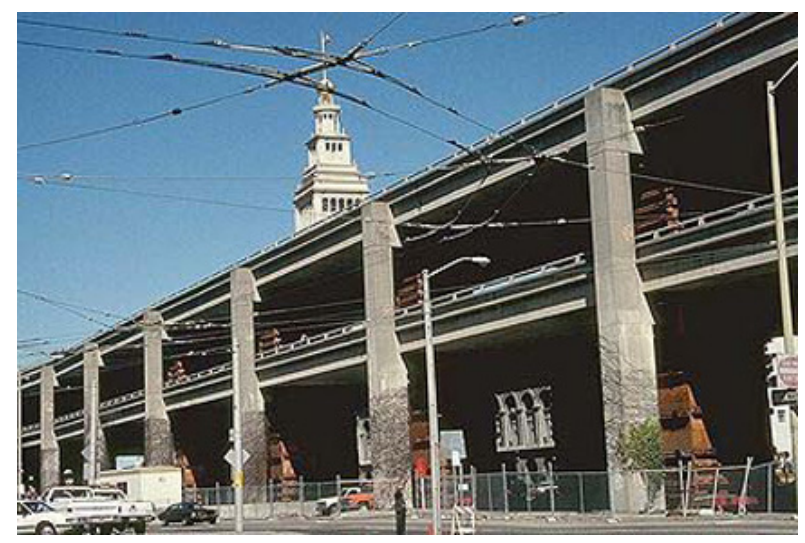

Figure 4: The ferry terminal building obscured by the embarcadero freeway, San Francisco. Courtesy of G. Donald Bain.

dwellers but also of eliminating sizeable pieces of the urban fabric in which their lives played out that sparked a series of highway revolts in American cities (most notably in San Francisco) almost as soon as the Federal-Aid Highway Act of 1956 (commonly known as the National Interstate and Defense Highways Act) established the interstate highway system and the construction of urban highways began in earnest. In most cities, this resistance would not coalesce quickly enough to be effective. In these places, the Highway Act, especially in the decades immediately following its passage, became a tool not only for inserting a new infrastructure into the city, but also for systematically eliminating other infrastructures - typically in those areas of the city that needed them most desperately.

\section{The highway vs. "gentle infrastructure"}

The evidence is considerable that many federal programs have induced sharp imbalances in the 'ecology' of urban areas - the highway program, for example, is frequently charged with this, and there is wide agreement that other, specifically city-oriented programs such as urban renewal, have frequently accomplished just the opposite of their normal objectives. The reasons are increasingly evident. Cities are complex social systems. [15]

\section{- Daniel Patrick Moynihan}

It is perhaps not surprising that as planners and traffic engineers looked for ways to thread highways into American cities their choices gravitated toward areas of little economic, social, or political power. This process was going to get messy and the less resistance that could be generated by local residents the better. In fact, as early as 1939 no less a figure than Robert Moses haughtily warned that the urban portions of the interstate system would be, "the hardest to 
locate, the most difficult to clear, the most expensive to acquire and build, and the most controversial from the point of view of selfish and shortsighted opposition" [12, p. 678]. What is perhaps more shocking is that in many cases the destruction urban highways would visit upon underprivileged neighborhoods was seen as a benefit in its own right - if not equal in its desirability to the transportation function of the road itself, then at least a significant corollary. Inevitably, in many cities, this grew to be a struggle defined both by class and race.

The language used by planners of the day was at its worst racist, but even some of the milder examples with their matter-of-fact desire to eliminate entire poor neighborhoods can seem quite crass to our contemporary ears. Public Roads Administration Western Operations Chief Lawrence I. Hewes in 1945 stated that urban highways would target areas of, "obsolete buildings and lowered property values," requiring that they, "work hand in hand to obtain the maximum benefit in cleaning up those blighted sections" [14, p. 61]. Speaking of a proposed highway project for Baltimore in 1944 that was projected to eliminate the dilapidated housing of 19,000 citizens Robert Moses stated, "the more of them that are wiped out the healthier Baltimore will be in the long run" [12, p. 689]. As Mindy Thompson Fullilove has put it:

Though downtown business leaders were interested in clearing blight, ghetto areas seemed to offer a two-fer: clear blight and clear blacks. They had at their disposal two mechanisms that ultimately worked synergistically to help clear the land: one was urban renewal, and the other was the federal highway program. Imagine, then, the triangle of the ghetto diminished by the half circle of downtown completing itself by urban renewal, while highway construction took a juicy slice, generally aimed straight down the middle [16].

Or, as it was more succinctly stated on a flier of protest distributed in Washington DC in the 1960's, "no more white highways through black bedrooms." By the late 1960's it was estimated that highway construction was eliminating over 62,000 units of housing per year [12, pp. 679-680].

It is here that the story of highway and the American city comes to its flashpoint, perhaps because it is where one type of infrastructure most clearly rubs up against and challenges another. On the one hand the highly engineered, speed oriented, single purpose infrastructure of the highway. On the other, complex systems so quiet and unassuming they hardly seem like infrastructure at all, and to which hardly anyone (at least in the business and political elite) attached any value. These, what are here termed "gentle infrastructures", are those so intricately described by Jane Jacobs, the patron saint of the highway revolt movement, such as sidewalks, neighborhood parks, and old buildings [17].

While the neighborhoods that bore the brunt of urban highway construction were in most cases economically disadvantaged, often they were the sites of viable communities. However, as with any complex urban community, they relied on these "gentle infrastructures" for their ability to function properly. It was through these robust but low cost means - old buildings, sidewalks, etc. that poor families were able to gain a toehold in the city, fledgling business were allowed to take chances, and the thousand daily interactions between people took 
place. The highway revolts of the 1960's and 1970's were joined by people with wide ranging concerns. Some were simply conservatives; some were neoluddites who were opposed to the car and its related trappings; others objected on aesthetic grounds. But the primary fuel to the revolt fire was to be found in the people (and those, like Jacobs, who stood with them) whose way of life was being suffocated through the elimination of its supporting framework.

\section{Coda: urban highways as catalysts}

While the highway revolts of the 1960's and 1970's met with varying degrees of success, in many American cities urban highways are today serving a purpose that was unimaginable to the protestors of the time - they are serving as placeholders for the reinsertion of complex systems of gentle infrastructure.

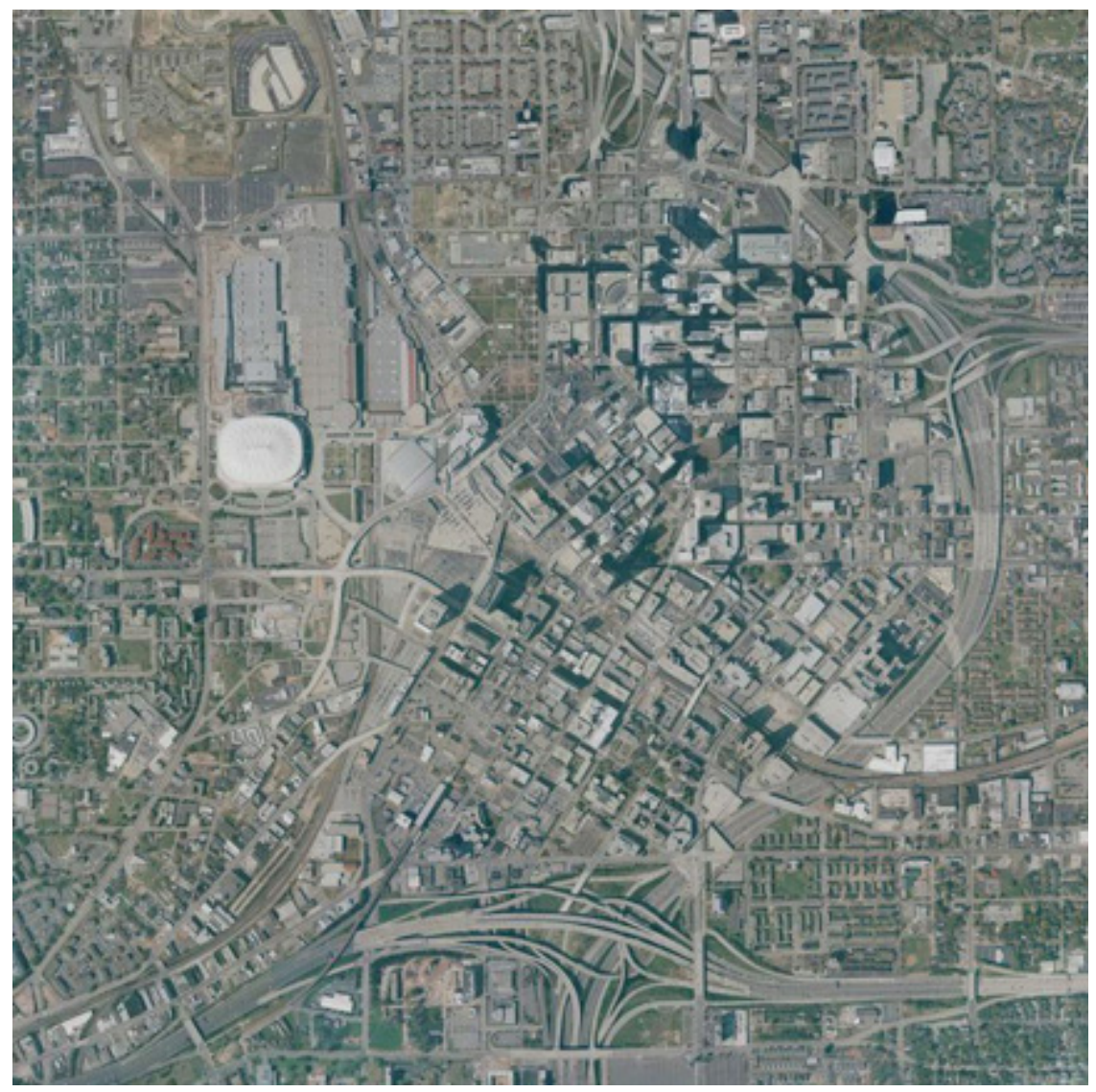

Figure 5: Interstates and exchanges around downtown Atlanta, Georgia. Courtesy of the United States Geological Survey. 
The West Side Highway itself is now gone; replaced, in places, with tree lined surface boulevards and bike lanes. The Big Dig has vanquished Boston's Central Artery and replaced it with the Rose Kennedy greenway. San Francisco has removed the Embarcadero Freeway and allowed Octavia Boulevard to flourish with playgrounds and sidewalk cafes in a space that was once dominated by an elevated highway. Seattle is in the planning stages of an effort that will remove the Alaskan Way Viaduct that currently cuts the city off from its own waterfront. The Civic Design Center in Nashville has developed and published a detailed plan for removing all radial interstates within the city's bypass loop [18]. Some of these projects involve the simple operation of giving the ground plane back over to pedestrians and slower forms of motorized traffic. Others eliminate targeted urban highways altogether; relying on new detailed understandings of the efficiencies of distributed grids revealed through complex modeling - something that Lewis Mumford understood intuitively in 1958 when he wrote that, "Highway planners have yet to realize that these arteries must not thrust into the delicate tissue of our cities; the blood they circulate must rather enter through [sic] elaborate network of minor blood vessels and capillaries" [19]. Gentle infrastructure is slowly reasserting itself.

As such projects become more commonplace and ambitious, might we begin to see these large swaths of publicly controlled urban land as assets of a type never before imagined? The greening of the American city is a linchpin of a sustainable global future. As we look for ways to retrofit our cities with the infrastructure of a green future - sustainable urban drainage systems, distributed renewable energy harvesting, district combined heat and power systems, small schools, light rail, bike lanes, neighborhood parks, and yes, charging stations for the amazing electric car (now part of a car share program) -much of the necessary urban real estate is right where we left it before it was co-opted by the highway. More than a century after the unfortunate death of Mr. Bliss, the car might yet find a comfortable place in the American city.

\section{References}

[1] "Fatally Hurt By Automobile", New York Times, September 14, 1899.

[2] For the electric car as urban savior see for example: Alliance for Clean Energy, "The Drive to Efficient Transportation", May 2005, http://ase.org/images/lib/transportation/Alliance_Transportation_Handbook .pdf (accessed 3 September 2009) or, Alok Jha, "London Mayor - 100,000 electric cars for capital", The Guardian, 8 April 2009.

[3] "Milestones in U.S. Car Safety", National Geographic, September 2009.

[4] In this paper the term "highway" is used broadly to denote a road whose primary design goal is the efficient transmission of automobiles and includes roads labeled by similar terms such as "expressway" and "interstate".

[5] Kay, Jane Holtz, Asphalt Nation: How the Automobile Took over America and How we can Take it Back, Crown Publishers, New York, p.151, 1997. 
[6] Rohatyn, F., Bold Endeavors: How our Government Built America, and Why it Must Rebuild Now, Simon and Schuster, New York, pp. 199-201, 2009.

[7] Macy, C. and Bonnemaison, S., Architecture and Nature: Creating the American Landscape, Routledge, New York, 2003.

[8] Duany, Andres, "Transect: Reconciling the Natural and the Urban", lecture delivered at the University of Tennessee, 1 March 2005.

[9] Pollan, Michael, A Place of My Own: the Education of an Amateur Builder, Random House, New York, pp. 104-107, 1997.

[10] "The Original Futurama", Wired, November 27, 2007. http://www.wired.com/entertainment/hollywood/magazine/1512/ff_futurama_original (accessed 9 September 2009).

[11] Marx, Leo, The Machine in the Garden: Technology and the Pastoral Ideal in America, Oxford University Press, Oxford, p. 195, 1964.

[12] Mohl, Raymond A., "Stop the Road: Freeway Revolts in American Cities", Journal of Urban History, 30; 693, 2004.

[13] Easterling, Keller, Organization Space: Landscapes, Highways, and Houses in America, MIT Press, Cambridge, p.76, 1999.

[14] Rose, Mark H., Interstate: Express Highway Politics 1941-1956, The Regents Press of Kansas, Lawrence, p. 57, 1979.

[15] Moynihan, D. P., "Toward a National Urban Policy" in Toward a National Urban Policy, Moynihan, D.P. ed., Basic Books, New York, p. 11, 1970.

[16] Fullilove, M., Root Shock: How Tearing Up City Neighborhoods Hurts America, Random House, New York, p. 64, 2004.

[17] Jacobs, Jane, The Death and Life of Great American Cities, Random House, New York, 1961.

[18] Kreyling, Christine, The Plan of Nashville: Avenues to a Great City, Vanderbilt University Press, Nashville, p. 72-92, 2005.

[19] Mumford, Lewis, "The Highway and the City", Architectural Record, April 1958, p. 181. 